\title{
Students' Attitude towards Entrepreneurship: Does Gender Matter?
}

\author{
Stavroula LASPITA \\ Simone CHLOSTA \\ Heinz Klandt \\ European Business School Reichartshausen, Oestrich-Winkel, Germany \\ Christian SCHEINER \\ Alexander BREM \\ Kai-Ingo VOIGT \\ University of Erlangen-Nuremberg, Nuremberg, Germany
}

\begin{abstract}
Over the last twenty years, academics and economic organizations demonstrated a growing interest in women entrepreneurs. Female Entrepreneurship $i$. considered to be one of the most important sources of growth, employment and innovati the United States, women owned businesses are the fastest growing sector of new ver overall. However, little is known about women entrepreneurs.

In contradiction to previous research, which focused on women and men during their professional activity, this study concentrates on an earlier point, namely before the of the professional career. This study aims at looking at gender-related differences in the context of self-employment. Family background, study-related factors and inhibiting and fostering factors that influence the choice of starting a business are examined.

The project was initiated by the University of Erlangen-Nuremberg and the European Business School in Oestrich-Winkel (Germany). The survey was conducted in 2006 and the sample includes 553 students.
\end{abstract}

Keywords: entrepreneurship, gender, students, motives, hurdles

\section{Introduction}

According to the Global Entrepreneurship Monitor (Sternberg and Lückgen, 2005) ${ }^{1}$ and the KfW Start-up Monitor 2005 (Hofmann et al., $2005)^{2}$ in Germany fewer women than men are interested in founding their own company (only 29\%), although women represent half of the employed population.

\footnotetext{
${ }^{1}$ Sternberg and Lückgen, 2005

${ }^{2}$ Hofmann et al., 2005
}

92 Volum 8, Număr 4, Decembrie 2007

Revista de Management Comparat Internațional 
Over the last twenty years, academics and economic organizations have demonstrated a growing interest in women entrepreneurs, especially in the United States and Canada where the number of women owned businesses has been rising. Female Entrepreneurship is now considered to be one of the sources of growth, employment, and innovation. In the United States, women owned businesses are the fastest growing sector of new ventures overall (Becker-Blease and Sohl, 2007) ${ }^{3}$. However, very little is known about women entrepreneurs (Orhan, 2001).

In contradiction to previous research, which concentrates on women and men during their professional activity, this study concentrates on an earlier point in time and that is before the working life begins: in the prestart-up phase. This means that situational factors, for example unemployment or worse career opportunities, that could occur after the commencement of business activities have not been experienced yet and can not influence the selection of the professional career (self-employment or not). For this reason, students were selected as a target group; as in most cases students do not start their professional career during their studies. The micro-social environment (family background, friends, etc.), entrepreneurial education and specific cognitions (fostering and hindering perceptions) towards self employment that influence the professional choice remain and are examined in this study.

Thus, the goal of this study is to cover a variety of influences on founding intention (family background, educational environment, and cognition) analyzed in regard to gender.

\section{Literature review}

The studies regarding gender-related differences can be assigned in general into two fundamental theories (Fischer et al., 1993) ${ }^{5}$. Liberal feminism as the first theory stems from the liberal political theory. Therein, it is argued that men and women are rational equal and do not differ in their capabilities and have, thus, the same potential in general. Observable rational differences between male and female entrepreneurs in their achievements are, hence, the result of certain kinds of discrimination during the socialization. While men have the opportunity to realize their full potential, women are hindered to do so due to their socialization. Liberal feminism concludes that if women are treated equally to men, the

\footnotetext{
${ }^{3}$ Becker-Blease and Sohl, 2007

${ }^{4}$ Orhan, 2001

${ }^{5}$ Fischer et al., 1993
} 
differences will diminish and women will be more like men. Social feminism is the second theory that serves as underlying base for research. Social feminism argues "that there are differences between males' and females' experiences from the earliest moments of life that result in fundamentally different ways of viewing the world" (Fischer et al., p.154) ${ }^{6}$. As a result of this, men and women develop different traits which are, however, not unequal effective to pursue a goal. In contrast to the liberal feminism, the social feminism is seen as the more appropriate theory to explain gender-related differences (Fischer et al., 1993) ${ }^{7}$ and will therefore, serve within this paper as base.

In literature that is based upon liberal feminism and on social feminism, there is no real consensus among scholars, whether small, large or if differences at all exist. Empirical findings seem to be diverse and in many cases contradictory. However, the field of female entrepreneurship and in extension gender differences in the founding behavior and in the entrepreneurial behavior has attracted some attention in the last twenty years (Sandberg, 2003 ${ }^{8}$; Mueller, 2004 ${ }^{9}$; Verheul and Thurik, 2001 ${ }^{10}$; Sexton, Bowman-Upton, $1990^{11}$; Birley $1989^{12}$ ).

\section{Male and female entrepreneurs}

At the beginning, some well-known statements will be summarized for an introduction to the topic (Rosa et al., 1996 ${ }^{13}$; Verheul and Thurik, $\left.2001^{14}\right)$ :

$\Rightarrow$ Female businesses under-perform in number of employees, sales turnover, etc.

$\Rightarrow$ Female business owners are less likely to own multiple businesses, less eager to plan expansion and tend to start smaller businesses with a smaller amount of start-up capital than men.

$\Rightarrow$ The value of assets in female businesses is significantly lower than in male businesses.

\footnotetext{
${ }^{6}$ Fischer et al., 1993

${ }^{7}$ Fischer et al., 1993

8 Sandberg, 2003

${ }^{9}$ Mueller, 2004

${ }^{10}$ Verheul and Thurik, 2001

${ }^{11}$ Sexton, Bowman-Upton, 1990

${ }^{12}$ Birley 1989

${ }^{13}$ Rosa et al., 1996

${ }^{14}$ Verheul and Thurik, 2001
}

94 Volum 8, Număr 4, Decembrie 2007

Revista de Management Comparat Internațional 
$\Rightarrow$ Men are more likely to want to grow their own business as far as they can, while female entrepreneurs prefer working part-time and in the service sector.

$\Rightarrow$ In comparison to men, women are more risk averse and spend less time on networking.

Thus, female and male entrepreneurs differ with respect to their personal and business profile: they start and run businesses in different sectors, develop different products, pursue different goals and structure their businesses in a different fashion (Brush, 1992 ${ }^{15}$; Fischer et al., 1993 ${ }^{16}$; Chaganti and Parasuraman, $1996^{17}$; Carter et al., $1997^{18}$; Verheul $2003^{19}$ ). Despite the mentioned economic importance of female entrepreneurs, their number still lags behind that of male entrepreneurs. According to Reynolds et al. $(2002)^{20}$ men are about twice as likely to be involved in entrepreneurial activity as women and Minniti et al. $(2005)^{21}$ show that in all countries participating in the Global Entrepreneurship Monitor in 2004 men are more active in entrepreneurship than women (Verheul et al., $2006)^{22}$.

Hence, men are more likely to be self-employed than women (Dolton and Makepeace, 1990) ${ }^{23}$. Entrepreneurial women are less likely then male entrepreneurs to be motivated by financial success and advancement, but by family and lifestyle (DeMartino and Barbato, 2003) ${ }^{24}$. Other studies emphasize the importance of independence, selfaccomplishment and quality of life (Orhan, 2001 ${ }^{25}$; Bennett and Dann, $2000^{26}$; Bradley and Boles, $2003^{27}$ ). Especially need for independence plays an important role (Carter and Cannon, 1988) ${ }^{28}$. The three most important factors influencing women in becoming entrepreneurs are according to Ufuk and Oezgen $(2001)^{29}$ : meeting the family needs, initiating social relations, and self-fulfilment.

\footnotetext{
${ }^{15}$ Brush, 1992

${ }^{16}$ Fischer et al., 1993

${ }^{17}$ Chaganti and Parasuraman, 1996

${ }^{18}$ Carter et al., 1997

${ }^{19}$ Verheul, 2003

${ }^{20}$ Reynolds et al., 2002

${ }^{21}$ Minniti et al., 2005

${ }^{22}$ Verheul et al., 2006

${ }^{23}$ Dolton and Makepeace, 1990

${ }^{24}$ DeMartino and Barbato, 2003

${ }^{25}$ Orhan, 2001

${ }^{26}$ Bennett and Dann, 2000

${ }^{27}$ Bradley and Boles, 2003

${ }^{28}$ Carter and Cannon, 1988

${ }^{29}$ Ufuk and Oezgen, 2001
} 
In contrast, financial gain is a strong motivation for males in general (Wilson et al., 2004) $)^{30}$, and less for women (Bradley and Boles, 2003) ${ }^{31}$. Similar conclusions are made by Ljunggren and Kolvereid (1996) ${ }^{32}$, who found that women are to perceive themselves as possessing higher entrepreneurial abilities than men do. Still, there is some evidence that women are less successful in these issues (Johnson and Storey, 1993) ${ }^{33}$ or at least often not taken as seriously as men are (Koper, 1993) ${ }^{34}$.

Besides the gender gap that is existent in venture creation and ownership activity, clear differences between the two genders exist as far as the founding setting is concerned. The fear of failure is more dominant to women as to men (Sternberg et al., $2004^{35}$ ). Moreover, women are more likely to stress personal expectancies while men are more likely to stress economic expectancies during the start-up process of a firm (Ljunggren and Kolvereid, 1996) ${ }^{36}$.

Facing their personal situation, in general the probability of selfemployment rises with age and number of children (Dolton and Makepeace, $1990)^{37}$. Furthermore, there is some evidence that women entrepreneurs tend to be older than their male counterparts (Johnson and Storey, 1993 ${ }^{38}$; Bennett and Dann, 2000 ${ }^{39}$ ). But, as Kolvereid (1996) ${ }^{40}$ argues, family background, gender, and self-employment experience only indirectly influence intentions to become self-employed through their effect on attitude, subjective norm and perceived behavioural control.

\section{Business foundation intentions}

An issue that should be stated is that most of the literature mentioned before focuses on differences or similarities between the two genders after the commencement of the business activities and that is during the start-up or the later phases of the corporate development. The pre-startup phase seems to be neglected or at least it has not attracted the attention that it should have. There are several models that deal with the related

\footnotetext{
${ }^{30}$ Wilson et al., 2004

${ }^{31}$ Bradley and Boles, 2003

${ }^{32}$ Ljunggren and Kolvereid, 1996

33 Johnson and Storey, 1993

${ }^{34}$ Koper, 1993

35 Sternberg et al., 2004

${ }^{36}$ Ljunggren and Kolvereid, 1996

${ }^{37}$ Dolton and Makepeace, 1990

38 Johnson and Storey, 1993

${ }^{39}$ Bennett and Dann, 2000

${ }^{40}$ Kolvereid (1996)
} 
corporate life cycle. These models vary from two stages (Dodge et al., $1994)^{41}$ to ten stages (Adizes, 1999) ${ }^{42}$. It is quite surprising that most of the models begin with the start-up phase and go on to the early development phase, but very few include the pre-start-up phase as a stage of the corporate development. However, it is in that particular phase that factors like personal intentions, motivation and family background etc. play the most important role in the employment status choice. The employment status choice has been defined by Katz (1992) ${ }^{43}$ as "the vocational decision process in terms of the individual's decision to enter an occupation as a wage-or-salaried individual or a self employed one." (p. 30)

Whereas research on entrepreneurship has been fostering the past years, there is a limited number of studies that focus on entrepreneurial intention among students. Wang and Wong (2004) ${ }^{44}$ concentrated on the level and the determinants of interest in entrepreneurship among university students in Singapore and have found among others that whereas students evaluated their business knowledge as poor, their interest to start-up a company is high. Scott and Twomey $(1988)^{45}$ focused on university students' career aspiration in three countries, namely the USA, the U.K and Ireland, and found that the U.S sample aspiring to self-employment was low (25\%) in comparison to the U.K. with $41 \%$ and Ireland with 34\%. In a 1996 survey of 372 Norwegian business graduates, Kolvereid (1996 ${ }^{46}$ found that $38 \%$ preferred self-employment. Lüthje and Franke $(2003)^{47}$ report that from a sample 2.193 engineering students, $44 \%$ indicate that they would quite probably and $11 \%$ that they would very probably run their own company after the completion of their studies. From the interviewed students only a $3 \%$ were already self-employed.

According to Kourilsky and Walstad (1998) ${ }^{48}$, females are significantly less likely than males $(62 \%-72 \%)$ to want to start their own business. Building on this and on the fact that there is indeed a gender gap in business ownership with more men being self employed than females, the first hypothesis is derived.

H1: The level of entrepreneurial intention is related to gender, males' intention is higher.

\footnotetext{
${ }^{41}$ Dodge et al., 1994

${ }^{42}$ Adizes, 1999

${ }^{43}$ Katz (1992)

${ }^{44}$ Wang and Wong, 2004

${ }^{45}$ Scott and Twomey, 1988

${ }^{46}$ Kolvereid (1996)

${ }^{47}$ Lüthje and Franke, 2003

${ }^{48}$ Kourilsky and Walstad, 1998
} 


\section{The influence of the family background}

Sing and DeNoble $(2003)^{49}$ found that personality, gender and having a close self-employed relative altogether have a strong positive relation to attitude on self-employment. In this context, Chen (1998) ${ }^{50}$ states that the number of entrepreneurial friends and relatives and the number of management courses were positive related to entrepreneurial decision and that male students expressed stronger intention toward becoming an entrepreneur than female students did.

In 1984, Klandt could show that the micro-social environment effects founding activity. This variable includes the family environment, i.e. where the person grew up as well as the family which he/she founded. Referring to Klandt $(1984)^{51}$, the father's profession has an effect on the occupational decision of the son and the daughter, while the mother's influence is limited to the daughter. Thus, the father's profession seems to have a more universal influence. This study includes both the father's and the mother's self-employment as a further predictor of the personal goals and success perceptions of students.

Hence, there is some evidence, that children of entrepreneurs are more likely to found a company than others (Scott and Twomey, 1988 ${ }^{52}$; Wang and Wong, 2004 ${ }^{53}$ ). For example, a study from Benett and Dann $(2000)^{54}$ indicates that almost half of the researched entrepreneurs had selfemployed parents.

The present study investigates whether males with self-employed parents are more likely to be interested in founding their own business than females with the same family background. Going a step further it is differentiated between the influence of the father and the mother on the children's intention to become self employed.

H2: Males with self-employed parents are more likely to be interested in founding their own business than females with the same family background.

\footnotetext{
${ }^{49}$ Sing and DeNoble, 2003

${ }^{50}$ Chen, 1998

${ }^{51}$ Klandt, 1984

${ }^{52}$ Scott and Twomey, 1988

${ }^{53}$ Wang and Wong, 2004

${ }^{54}$ Benett and Dann, 2000
} 


\section{The influence of the educational environment}

Lee and Wong $(2003)^{55}$ found that there is a positive relationship between entrepreneurship education and the intention to start a business. This was also found and confirmed by the study of Voigt et al. (2006) $)^{56}$ and Souitaris et al. $(2007)^{57}$. In general, positive prior experience affects the perceptions of the desirability of starting a business (Peterman \& Kennedy, 2003). A critical factor for successful entrepreneurship education is to include charismatic instructors who can communicate their enthusiasm for entrepreneurship through non-verbal expressiveness, because this will inspire students, which leads to a higher level of entrepreneurial intention. So the greater the inspiration from an entrepreneurship programme, the higher the students "post-programme" increase in attitude towards subjective norm and the intention to become self-employed (Souitaris et al., 2007). ${ }^{58}$

Whereas in the USA entrepreneurial courses in higher education are offered since 1947 and there are chairs as early as the mid-60s, in Germany, the first chair of entrepreneurship was only established in 1997 at the European Business School (Klandt, 2006) ${ }^{59}$. Fortunately the situation in Germany is improving, as in 2006 there are more or less 60 professors specialized in the field (Klandt, 2006) ${ }^{60}$. This could be a step that would lead in a transition from an education that only prepares students to become employees or managers of large companies to an education that also prepares students or at least gives the knowledge of how to become selfemployed.

Therefore the influence of the field of study, the chosen major, the entrepreneurial education on the founding intention will be investigated under the assumption that men posses a higher interest in becoming selfemployed.

H3a: Males whose field of study is business administration have higher interest in becoming self-employed than females.

H3b: Males who have chosen entrepreneurship as their major have higher interest in becoming self-employed than females.

H3c: Males that have attended courses in entrepreneurship have higher interest in becoming self-employed than females.

\footnotetext{
${ }^{55}$ Lee and Wong, 2003

${ }^{56}$ Voigt et al., 2006

${ }^{57}$ Souitaris et al., 2007

${ }^{58}$ Souitaris et al. (2007)

${ }^{59}$ Klandt, 2006

${ }^{60}$ Klandt, 2006
} 


\section{Perceived inhibiting (hurdles) and fostering (motives) factors towards the founding intention}

Within the literature a plethora of studies can be found that analyses the perception of inhibiting and fostering factors of students (Möller and Buttler, $1998^{61}$; Görisch et al., 2002 ${ }^{62}$; Voigt et al., $2006^{63}$; etc.). Möller and Buttler $(1998)^{64}$ found that the important founding reservations were the lack of start-up finance and the high degree of risk. Especially students with a low intention to start an own business saw those reasons as hindering factors. Furthermore, "Too much work and too little spare time" was named as an important hindering factor. The main distinction between students with a low interest in starting an own business and those who showed a medium to high interest was the missing business idea. Concerning the fostering factors, independence and a better opportunity for self-realisation were named as reasons to start an own business. Within the financial motives, the opportunity for profit was not as important as the financial reward for one's own initiative. Hence, it can be assumed that mainly inhibiting factors influence the founding intention. The results of Voigt et al. (2006) ${ }^{65}$ indicated as well that especially inhibiting factors seem to have the main impact on the founding intention.

Within the study of Görisch et al. (2002) ${ }^{66}$ only inhibiting factors were analysed. The main important inhibiting factor was the lack of start-up finance. Students with an interest in founding a business and those who would prefer an employment status differ in the motive of high personal risk as the latter perceived this factor as the second most problematic while for the former it played a minor role.

All studies have in common that fostering and inhibiting factors were not analysed in regard to the influence of gender. However, bearing in mind the basic assumption of the social feminism, that women differ fundamentally from men due to their socialisation, it is necessary to analyse how gender affects the influence of inhibiting and fostering factors on the founding intention. Therefore, the influence of inhibiting and fostering factors on the founding intention through the gender-lens will be investigated.

\footnotetext{
${ }^{61}$ Möller and Buttler, 1998

${ }^{62}$ Görisch et al., 2002

${ }^{63}$ Voigt et al., 2006

${ }^{64}$ Möller and Buttler, 1998

${ }^{65}$ Voigt et al., 2006

${ }^{66}$ Görisch et al., 2002
} 
H4a: Inhibiting factors towards founding a company influence founding intention negatively. Gender differences in the perception of the factors are expected.

H4b: Fostering factors towards founding a company influence founding intention positively. Gender differences in the perception of the factors are expected.

\section{Methodology \\ Research methodology}

The research process consisted of a four-step procedure which is orientated on an approach suggested by Kinnear and Taylor $(1991)^{67}$. First, the identification and concretion of the research objective was done. Second, a written standardized questionnaire was compiled. Closed-ended questions were chosen, so that the respondents had to choose between the reply alternatives given (Schnell et al., 1995) ${ }^{68}$. Furthermore, the questionnaire was designed in a manner to fulfil necessary requirements regarding clarity, clearness and simplicity of the questions. Therefore, the structure of the questions was orientated on a procedure suggest by Zikmund (1982) ${ }^{69}$ and Proctor (2000) ${ }^{70}$ which sees general and easy questions at the beginning and sensible or rather difficult questions at end of the questionnaire. Third, test interviews were conducted to improve the questionnaire. Therein, the debriefing method and the protocol method were used (Proctor, 2000) $)^{71}$. Test persons were students from the business faculty as well as senior research assistances from marketing and statistical chairs at the university. To ensure that also exchange students would be able to answer the questions, also non-German-native-speakers were members of the test group. The forth step was the data collection.

\section{Operationalisation of the variables \\ Intention}

In order to measure entrepreneurial intention, the validated scale by Klandt (1984) ${ }^{72}$ was applied. The question used was "Have you personally ever thought about founding your own business?". Possible answers are

\footnotetext{
${ }^{67}$ Kinnear and Taylor, 1991

${ }^{68}$ Schnell et al., 1995

${ }^{69}$ Zikmund, 1982

${ }^{70}$ Proctor, 2000

${ }^{71}$ Proctor , 2000

${ }^{72}$ Klandt, 1984
} 
varying from 1 (=no, not yet), 2 (=yes, occasionally), 3 (=yes, relatively concrete) to 4 (=yes, I have made the decision to become self-employed).

\section{Family Background}

To measure the family background of the participants a scale of Möller and Buttler (1998) ${ }^{73}$ was applied. "Manual, skilled or semi-skilled worker", "Salaried professional etc.", "Government employee", "Entrepreneur", "Freelancer or other self-employed" as well as "Other(s)" were given as answer alternatives.

\section{Fostering and Inhibiting Factors}

To measure the perception of fostering and inhibiting factors the scale of Möller and Buttler (1998) ${ }^{74}$ was applied. Concerning the fostering factors the question was used "Please indicate which statement would best describe your feelings about starting a business" or respectively for the inhibiting factors "Please indicate which statement would best describe your feelings about NOT starting a business". Answer alternatives reached from 5 (=totally agree ), 4 (=slightly agree), 3 (=neither...nor); 2 (=slightly disagree) to 1 (=totally disagree).

\section{Data collection and sample characteristics}

The survey was conducted in winter 2006 at the Business School of the University of Erlangen-Nuremberg. The project was initiated and coordinated by the University of Erlangen-Nuremberg in Nuremberg (Germany) and the European Business School in Oestrich-Winkel (Germany). The questionnaire itself was handed out to the students.

The sample of this study comprises 553 students from the Business School of Nuremberg. The proportion of men and women is even. The average student is 23 years old, is in the fifth semester, single and has not attended entrepreneurship lectures. Furthermore, the majority of almost $70 \%$ (67,5\% male students and 68,9\% female students) has chosen business administration as the major field of study. Out of these, 44 students (28 male and 16 female) decided to focus on the business start-up and entrepreneurship programme of the University of Erlangen-Nuremberg. Looking at the family background, almost $26 \%$ of the male students had a self-employed father and $12 \%$ a self-employed mother. In total the female students showed more often an entrepreneurial family background, as almost $30 \%$ have a self-employed father and $16 \%$ a self-employed mother.

\footnotetext{
${ }^{73}$ Möller and Buttler, 1998
}

${ }^{74}$ Möller and Buttler, 1998 


\section{Results}

The results will be presented in two parts. First, some descriptive findings will be presented and then the focus will be on the findings from the hypothesis testing.

\section{Descriptive findings}

The descriptives show that within this sample the founding intention is quite low as more than half of the students, both male and female, thought only occasionally about founding a business (see table 1). If the mean score for the whole sample is taken into consideration (AM:1.1, $\mathrm{SD}: 1.01)$ then it can be stated that there is almost no intention from the side of the student to become self-employed.

Have you personally ever thought about founding your own business?

Table 1

\begin{tabular}{lll}
\hline Founding Intentions & $\begin{array}{l}\text { Percent } \\
\text { male }\end{array}$ & female \\
\hline No, not yet & 17,8 & 28,9 \\
Yes, occasionally & 55,8 & 57,0 \\
Yes, relatively concrete & 16,9 & 8,6 \\
Yes, I have decided to become self employed & 9,5 & 5,5 \\
Total & $\mathbf{1 0 0}$ & $\mathbf{1 0 0 , 0}$ \\
\hline
\end{tabular}

Table 2 presents the mean and standard deviation results as far as the inhibiting variables are concerned. In all cases female students perceive the inhibiting variables more intimidating (preventing them from founding) than male students do.

Please indicate which statement would best describe your feelings about NOT starting a business

Table 2

(5=totally agree to $1=$ totally disagree)

\begin{tabular}{|c|c|c|c|c|c|}
\hline \multicolumn{3}{|c|}{ Male } & \multirow{2}{*}{ Inhibiting variables } & \multicolumn{2}{|c|}{ Female } \\
\hline $\mathrm{AM}$ & & SD & & $\mathrm{AM}$ & SD \\
\hline 2,65 & 1,29 & & Missing business knowledge & 2,98 & 1,39 \\
\hline 3,58 & 1,35 & & Missing concrete business idea & 3,69 & 1,37 \\
\hline 3,65 & 1,22 & & Missing seed capital & 3,81 & 1,26 \\
\hline 3,52 & 1,20 & & Insufficient practical experience & 3,77 & 1,21 \\
\hline 2,59 & 1,47 & & General missing interest & 2,97 & 1,54 \\
\hline 2,80 & 1,21 & & Missing founding partner /team & 3,07 & 1,29 \\
\hline 3,25 & 1,27 & & Missing business network & 3,48 & 1,22 \\
\hline
\end{tabular}




\begin{tabular}{|c|c|c|c|c|c|}
\hline \multicolumn{3}{|c|}{ Male } & \multirow{2}{*}{ Inhibiting variables } & \multicolumn{2}{|c|}{ Female } \\
\hline $\mathrm{AM}$ & & SD & & AM & SD \\
\hline 3,26 & 1,20 & & Missing market knowledge & 3,42 & 1,25 \\
\hline 3,02 & 1,09 & & Missing market transparency & 3,18 & 1,16 \\
\hline 2,10 & 1,30 & & Spouse or partner disapproves idea & 2,13 & 1,26 \\
\hline 3,66 & 1,71 & & High financial risk & 3,90 & 1,09 \\
\hline 2,84 & 1,15 & & Low income & 3,06 & 1,18 \\
\hline 2,90 & 1,81 & & Too much work for too less money & 3,10 & 1,29 \\
\hline 317 & 120 & & Too much work and too less spare- & 324 & 131 \\
\hline 2,88 & 1,08 & & Bad economic climate & 3,20 & 1,23 \\
\hline 2,42 & 1,19 & & Bound to the own company & 2,72 & 1,31 \\
\hline 3,39 & 1,32 & & Risk of failure & 3,63 & 1,25 \\
\hline 2,19 & 1,08 & & Missing social appreciation & 2,36 & 1,21 \\
\hline
\end{tabular}

In Table 3 the mean and standard deviation results for the fostering variables are presented. In almost all cases female students perceive the fostering variables as more important for their founding intention than male students do.

Please indicate which statement would best describe your feelings about starting a business

Table 3

(5=totally agree to $1=$ totally disagree)

\begin{tabular}{cclcc}
\hline & Male & \multicolumn{1}{c}{ Fostering variables } & Female \\
AM & SD & AM & SD \\
\hline 3,85 & 1,86 & Self-realisation & 4,11 & 0,93 \\
4,06 & 1,11 & Higher independency & 4,11 & 0,92 \\
3,29 & 1,21 & Put studied into action & 3,44 & 1,10 \\
4,09 & 0,97 & Higher autonomy of decision & 4,13 & 0,88 \\
2,85 & 1,73 & Good economic climate & 3,09 & 1,90 \\
& & Realize idea/ Pursue own & & \\
4,15 & 0,95 & business idea & 4,26 & 0,84 \\
3,54 & 1,07 & Gain experience & 3,73 & 1,03 \\
3,95 & 1,01 & Bear responsibility & 3,87 & 1,00 \\
3,14 & 1,19 & Higher prestige/ social status & 3,07 & 1,09 \\
3,66 & 1,16 & Higher income & 3,63 & 1,04 \\
3,84 & 1,06 & Potential profit & 3,69 & 1,03 \\
2,53 & 1,53 & Continue family business & 2,87 & 1,20 \\
2,67 & 1,26 & Motivation by friends and family & 3,10 & 1,29 \\
\hline
\end{tabular}




\section{Hypotheses testing}

Hypothesis 1 stated that the level of entrepreneurial intention is related to gender and that males' intention is expected to be higher. The mean regarding the founding intention of male students is 1,28 (SD 1,063), for females is 0,96 (SD 0.932). The T-Test (95\%) showed significant differences in the founding intention between the genders (table 4). Therefore hypothesis 1 is confirmed by the analysis of the data and this result is in accordance with recent research.

t- Test, gender differences in the founding intention

\begin{tabular}{|r|l|l|l|}
\hline \multicolumn{2}{|c}{} & \multicolumn{2}{c|}{ Table 4 } \\
\hline Intention & $\mathrm{t}$ & $\mathrm{df}$ & $\mathrm{p}$ \\
\hline
\end{tabular}

$\mathrm{n}=498, \mathrm{t}=\mathrm{t}$ value, $\mathrm{df}=$ degrees of freedom, $\mathrm{p}=$ significance at the $5 \%$ level

The second hypothesis and namely that males with self-employed parents are more likely to be interested in founding their own business than females with the same family background was only partially confirmed by the data. A T-Test was conducted separately for the influence of the father's and the mother's self-employment on the founding intention of the children. Regarding the influence of the father (table 5), significant differences in the mean intention were found between male and female students (with males showing higher intention $A M=1,56$ vs $A M=1,12$ ). However the same does not apply for the influence of the mother. No significant differences (table 6 ) could be found in the mean intention of males and females. Therefore the family background plays indeed a role in the formation of the entrepreneurial intention of the male and female students but the influence of the father is stronger than that of the mother.

t- Test, gender differences, influence of father's self-employment on founding intention

\begin{tabular}{|l|l|l|l|}
\multicolumn{2}{|c}{ Table 5 } \\
\hline & $\mathrm{t}$ & $\mathrm{df}$ & $\mathrm{p}$ \\
\hline Intention & 1,981 & 116 &, 049 \\
\hline
\end{tabular}

$\mathrm{n}=118, \mathrm{t}=\mathrm{t}$ value, $\mathrm{df}=$ degrees of freedom, $\mathrm{p}=$ significance at the $5 \%$ level

t- Test, gender differences, influence of mother's self-employment on founding intention

\begin{tabular}{|r|l|l|l|}
\multicolumn{2}{c}{ Table 6 } \\
\hline & $\mathrm{t}$ & $\mathrm{df}$ & $\mathrm{p}$ \\
\hline Intention & $-0,323$ & 66 &, 748 \\
\hline
\end{tabular}

$\mathrm{n}=68, \mathrm{t}=\mathrm{t}$ value, $\mathrm{df}=$ degrees of freedom, $\mathrm{p}=$ significance at the $5 \%$ level 
As far as the influence of the education is concerned not all hypothesis are accepted. Hypothesis $3 \mathrm{a}$ on the field of study and entrepreneurial intention among males and females is accepted by the TTest analysis. Males whose field of study is business administration have higher interest in becoming self-employed than females (AM: 1,39 for male students vs. 1,02 for female students) and the difference is statistically significant (table 7). In testing hypothesis $3 \mathrm{~b}$, surprisingly the conducted TTest (table 8) showed no significant differences in the founding intentions of males and females that have chosen Entrepreneurship as a major. Thus, this hypothesis is rejected by the data of this study. Once more surprisingly the conducted T-Test (table 9) showed no significant differences in the founding intentions of males and females who had attended courses in entrepreneurship. Male students however seem to have a slightly higher intention to become self employed than female students after they attended courses in Entrepreneurship (AM: 1,45 for male students vs. 1,33 for female students). Hence, also this hypothesis can not be confirmed in this study.

\section{t- Test, gender differences, influence of field of study on founding intention}

\begin{tabular}{|l|l|l|l|}
\hline \multicolumn{2}{|c}{ Table 7 } \\
\hline & $\mathrm{t}$ & $\mathrm{df}$ & $\mathrm{p}$ \\
\hline Intention & 3,240 & 334 &, 001 \\
\hline
\end{tabular}

$\mathrm{n}=336, \mathrm{t}=\mathrm{t}$ value, $\mathrm{df}=$ degrees of freedom, $\mathrm{p}=$ significance at the $5 \%$ level

t- Test, gender differences, influence of major on founding intention

Table 8

\begin{tabular}{|r|l|l|l|}
\hline & $\mathrm{t}$ & $\mathrm{df}$ & $\mathrm{p}$ \\
\hline Intention & 1,878 & 36 &, 68 \\
\hline
\end{tabular}

$\mathrm{n}=38, \mathrm{t}=\mathrm{t}$ value, $\mathrm{df}=$ degrees of freedom, $\mathrm{p}=$ significance at the $5 \%$ level

t- Test, gender differences, influence of courses in entrepreneurship on founding intention

\begin{tabular}{|l|l|l|l|}
\hline & \multicolumn{2}{c|}{ Table 9 } \\
\hline Intention & $\mathrm{t}$ & $\mathrm{df}$ & $\mathrm{p}$ \\
\hline
\end{tabular}

$\mathrm{n}=104, \mathrm{t}=\mathrm{t}$ value, $\mathrm{df}=$ degrees of freedom, $\mathrm{p}=$ significance at the $5 \%$ level

As previously already stated various fostering and inhibiting variables towards entrepreneurship were taken into consideration for this study. A confirmatory factor analysis (varimax rotation, main component 
analysis) reduced the 18 different inhibiting variables into four factors. These are: lack of pre start-up know-how, financial and failure risks, lack of interest and ideas, social hindrances. The four factors together explain a total of 57,57 percent of the variance. The first factor includes items like little market knowledge, no partner, and no practical experience and explains 35,19 percent of the variance. In the financial and failure risk factor the fear of large financial risk, too much work and the fear of failure are included $(9,18$ percent of the variance). The third factor includes no interest and no ideas ( 7,87 percent of the variance). Finally the social hindrances are no family support and no prestige (5,33 percent of the variance).

The correlation analysis (Table 10) for the whole sample (both male and female students) shows that there is a negative relationship between all the inhibiting factors and the founding intention. In other words the stronger the inhibiting factors are perceived the lower becomes the intention to become self-employed. The correlation between intention and the social hindrance factor is quite low $(-, 092)$ but still negative and significant at the 5\% significance level. These results confirm the first part of the hypothesis $4 \mathrm{a}$.

Correlation analysis, intention and hindering factors

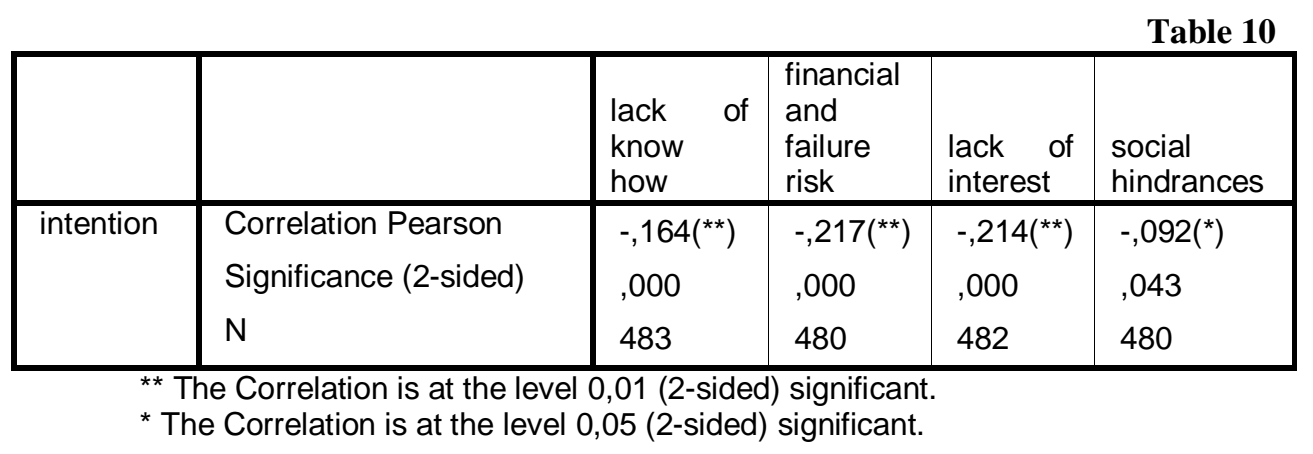

To test whether differences in the perception of the hindering factors between the two gender exist, two separate linear regression analyses for the male and female sample were conducted (the exact results of the regression analysis can be found in the appendices). As independent variables the four inhibiting factors have been used with the founding intention as dependent variable. For the male sample only the lack of interest factor was significant (beta value $=-0,162$ ) and all the factors explain $5,3 \%$ of the variance in intention. The regression analysis for the women sample shows that the 
financial risk factor is the only significant influence (beta value $=-0,225$ ). Here almost $8 \%$ of intention variance is explained $\left(\mathrm{R}^{2}\right)$.

In the case of the fostering variables once more a confirmatory factor analysis (with four factors, varimax rotation, and main component analysis) has been conducted. The 13 fostering factors were reduced to four factors and namely: independence, status, external factors and experience. The four factors explain 66,89 percent of the variance. The independence factor includes striving for independence and freedom in decision making and explains 34,77 percent of the variance. The status factors includes items like higher prestige, higher income (14,07 percent of the variance). External factors are motivation by family and friends as well as good market conditions (11,02 percent of the variance). Finally the experience factor consists of the variables making one's own experience and putting knowledge into practice.

The correlation analysis (table 11) for the whole sample (both male and female students) shows that there is a positive relationship between three fostering factors and the founding intention. This means that the stronger the fostering factors are perceived the higher becomes the intention to become self-employed. The correlation between intention and external factors is not significant. These results partially confirm the first part of the hypothesis $4 \mathrm{~b}$.

\section{Correlation analysis, intention and fostering factors}

Table 11

\begin{tabular}{|l|l|l|l|l|l|}
\hline & & independence & status & external & experience \\
\hline intention & Correlation Pearson &, $248\left(^{* *}\right)$ &, $117\left(^{*}\right)$ &, 086 &, $180\left(^{* *}\right)$ \\
& Significance (2-sided) &, 000 &, 010 &, 059 &, 000 \\
& $N$ & 484 & 483 & 483 & 484 \\
\hline
\end{tabular}

Once more two separate linear regression analyses has been conducted for the female and the male sample, to test whether differences in the perception of the hindering factors between the two gender exist (the exact results of the regression analysis can be found in the appendices). Regarding the male group, all the factors explain approximately $9 \%$ of the variance, whereas only the independence factor is significant (beta value= 0,245). As far as women are concerned, all the fostering factors explain around $6 \%$ of the variance of the founding intention. Here as well only the independence factor is significant (beta value $=0,163$ ).

108 Volum 8, Număr 4, Decembrie 2007

Revista de Management Comparat Internațional 


\section{Discussion and conclusion}

The comparison in the founding intention between males and females showed significant differences. This result confirms the conventional wisdom that the entrepreneurial intention of males is higher than those of females (e.g. Kourilsky and Walstad, 1998 ${ }^{75}$; Wang and Wong, 2004 ${ }^{76}$; Möller and Buttler, $1998^{77}$ ). It is therefore not only the founding activity of men higher but the founding intention as well.

In our sample the family background showed only partially a significant influence on founding intention, however, with the father's influence resulting only in significant differences in the founding intention of male and female students. So, our second hypothesis is only partially supported.

Also, our third hypothesis (H3a, H3b, H3c) which deals with studyrelated factors could only partly proved by this sample. When only looking at the field of study, males were more interested in founding one's own business than women. Our findings tend to indicate that there could be a positive relationship between general business administration education and the intention to start a business. Surprisingly entrepreneurship as major and courses in entrepreneurship did not bring significant differences in the founding intention of the two genders. Perhaps this is because the subsample that has chosen entrepreneurship as a major is quite low in number.

Hypothesis $4 \mathrm{a}$ assumed that inhibiting factors towards founding a company influence founding intention negatively. This part of the hypothesis is supported from our data. The second part of the hypothesis was only partially confirmed. The lack of interest factor was found significant only for men. The financial and failure risk was found significant only for women. Hence, females perceive the establishment of a new company as more risky (especially financial risk) than men. This is in accordance with the results of recent literature (e.g. Johnson and Storey, $1993^{78}$; Voigt et al., $2006^{79}$; Ljunggren and Kolvereid, $1996^{80}$; Sternberg et al., $\left.2004^{81}\right)$.

\footnotetext{
${ }^{75}$ Kourilsky and Walstad, 1998

${ }^{76}$ Wang and Wong, 2004

${ }^{77}$ Möller and Buttler, 1998

${ }^{78}$ Johnson and Storey, 1993

${ }^{79}$ Voigt et al., 2006

${ }^{80}$ Ljunggren and Kolvereid, 1996

${ }^{81}$ Sternberg et al., 2004
} 
Hypothesis $\mathrm{H} 4 \mathrm{~b}$ stated that fostering factors towards founding a company influence founding intention positively. This part of the hypothesis is accepted. When making the gender comparison for both groups only the independence factor is significant. Thus, the results are surprising, as men are generally supposed to be strongly focused by financial gain (Wilson et al., 2004 ${ }^{82}$; Bradley and Boles, $2003^{83}$ ). However our results show that men and women differ according to inhibiting factors but not regarding to fostering factors. Therefore the gender gap regarding the perception of a potential venture creation can only be partly supported.

\section{Implications for Entrepreneurship research and practice}

The research on German students with a focus on gender differences as far as founding a company is concerned should help in understanding the emergence of differences in the German founding landscape and in deducing recommendations for action. Furthermore this research should help us understand gender-related differences in founding intentions due to perception of various fostering and inhibiting factors.

As people before entrance into the working life were examined, influences of the working life can be controlled partially (not to 100\%). As the measurement already takes place at an early point in time (during the studies), it can be intervened in time, in order to finally strengthen the interest of founding a company and also the founding activity of women.

The results of our study could also have important implications for the academic field. The result that student's intention to become selfemployed is very low should serve a starting point for academics to rebuild entrepreneurship education. Adjusting the support activities and the lecture contents in a way that awakes the entrepreneurial interest for both male and female students is of great importance. In addition it seems that mostly women are lacking information about financial support when planning to found a business. This could be included in lectures, too.

\section{Limitations - suggestions for further research}

The selection of a single country has the obvious limitation of the generalizability of the results across populations and geographical settings. Furthermore, the limitation in generalizability also arises from the fact that the research took place in a specific time period, giving us a snapshot of the

\footnotetext{
${ }^{82}$ Wilson et al., 2004

${ }^{83}$ Bradley and Boles, 2003
}

110 Volum 8, Număr 4, Decembrie 2007

Revista de Management Comparat Internațional 
situation at a particular point in time. The results found, may not be applicable if the circumstances change. In addition, the survey was conducted at only one University, which could affect the explanatory content.

Of course intention can predict activity but it is not activity itself. In a further step a longitudinal study could enable a further look to whether students' intention to become self-employed has become realization and if not why. If on the other hand intention has become activity it is important to see the quality (in terms of turn over, number of employees, self realization of the founder, etc.) of the start ups founded by former students.

\section{References}

1 Adizes, I., Managing corporate lifecycles. Paramus, NJ, 1999.

2 Becker-Blease, J.R. - Sohl, J.E., "Do women-owned businesses have equal access to angel capital?" Journal of Business Venturing, Vol. 22, Iss. 4, p. 503-521, 2007.

3 Bennett, R. - Dann, S., The Changing Experience of Australian Female Entrepreneurs, Gender, Work \& Organization, Vol. 7, Iss. 2, p. 75-83, 2000.

4 Birley, S., "Female entrepreneurs: Are the really any different?" Journal of Small Business Management, Vol. 27, Iss. 1, p32-37, 1989.

5 Bradley, F. - Boles, K., Female entrepreneurs from ethnic backgrounds: an exploration of motivations and barriers, Manchester Metropolitan University Business School Working Paper Series. Available at: http://www.ribm.mmu.ac.uk/wps/papers/03-09.pdf, 2003.

6 Brush, C.G., Research on Women Business Owners: Past Trends, a New Perspective and Future Directions. Entrepreneurship Theory \& Practice, Vol. 16, Iss. 4, p. 5-30, 1992.

7 Carter, S. - Cannon, T., Women in Business, Department of Employment Research Paper, No. 65, 1988.

8 Carter, N.M. - Williams, M. - Reynolds, P.D., "Discontinuance among new firms in retail: The influence of initial resources, strategy, and gender", Journal of Business Venturing, Vol. 12, Iss. 2, p. 125-145, 1997.

9 Chaganti, R. - Parasuraman, S.A, Study of Impacts of Gender on Business Performance and Management Patterns in Small Business. Entrepreneurship: Theory \& Practice, Vol. 21, Iss. 2, p. 73-75, 1996.

10 Chen, C.C. - Greene, P.G. - Crick A., "Does entrepreneurial selfefficacy distinguish entrepreneurs from managers?" Journal of Business Venturing, No. 13, p. 295-316, 1998. 
11 DeMartino, R. - Barbato, R., "Differences between women and men MBA entrepreneurs: exploring family flexibility and wealth creation as career motivators", Journal of Business Venturing, Vol. 18, Iss. 6, p. 815-833, 2003.

12 Dodge, H. R. - Fullerton, S., - Robbins, J. E., "Stage of the organizational life cycle and competition as mediators of problem perception for small businesses", Strategic Management Journal, No. 15, p. 121-135, 1994.

13 Dolton, P. J. - Makepeace, G. H., Self Employment Among Graduates, Bulletin of Economic Research, Vol. 42, Iss. 1, p. 35-54, 1990.

14 Fischer, E. - Reuber, A. - Dyke, L., "A Theoretical Overview and Extension of Research on Sex, Gender, And Entrepreneurship", Journal of Business Venturing, Vol. 8, No. 2, p.151-168, 1993.

15 Görisch, J. - Kulicke, M. - Bruns, R. - Stahlecker, T. (2002) Studierende und Selbstständigkeit - Ergebnisse der EXISTStudierendenbefragung, Bonn, 2002.

16 Hofmann, C. - Tilleßen, P. - Zimmermann V., KfW-Gründungsmonitor 2005.

17 Johnson, S. - Storey, D., "Male and female entrepreneurs and their businesses: A comparative study". In S. Allen \& C. Truman (Eds.), Women in business: Perspectives on women entrepreneurs, Routledge: London, p. 70-85, 1993.

18 Katz J., "A psychological cognitive model of employment status choice", Entrepreneurship Theory and Practice, No. 17, p. 29-36, 1992.

19 Kinnear, T. - Taylor, J., Marketing Research - An Applied Approach, 4th Edition. New York, 1991.

20 Klandt, H., Aktivität und Erfolg des Unternehmungsgründers. Eine empirische Analyse unter Einbeziehung des mikro-sozialen Umfeldes, Bergisch Gladbach, 1984.

21 Klandt, H.,Gründungsmanagement: Der Integrierte Unternehmensplan. (2 Auflage). Oldenbourg Verlag: Oldenbourg, 2006.

22 Kolvereid L., "Organizational employment versus self-employment: reasons for career choice intentions", Entrepreneurship Theory and Practice, No. 20, p. 23-31, 1996.

23 Kolvereid, L., "Prediction of employment status choice intentions", Entrepreneurship: Theory \& Practice, Vol. 21 Iss. 1, p. 47-58, 1996.

24 Koper, G., "Women entrepreneurs and the granting of business credit", in Allen, S, Truman, C. (Eds), Women in Business: Perspectives on Women Entrepreneurs, Routledge: London, 1993.

112 Volum 8, Număr 4, Decembrie 2007

Revista de Management Comparat Internațional 
25 Kourilsky M.L. - Walstad W.B., "Entrepreneurship and female youth: knowledge, attitudes, gender differences, and educational practices Entrepreneurship for the 21st Century", Journal of Business Venturing, Vol. 13, Iss. 1, p. 77-88, 1998.

26 Lee, L. - Wong, P.-K., "Attitude towards entrepreneurship education and new venture creation," Journal of Enterprising Culture, Vol. 11, Iss. 4, p. 339-357, 2003.

27 Ljunggren, E. - Kolvereid, L., "New business formation: does gender make a difference?" Women in Management Review, Vol. 11, Iss. 4, p. 3-12, 1996.

28 Lüthje, C. - Franke, N., "The 'making' of an entrepreneur: testing a model of entrepreneurial intent among engineering students at MIT", $R \& D$ Management, No. 33, p. 135-147, 2003.

29 Minniti, M. - Arenius, P. - Langowitz, N. - GEM Report on Women and Entrepreneurship, Available at:

http://www3.babson.edu/CWL/research/GEM-Report-on-Women-andEntrepreneurship.cfm, 2005.

30 Möller, I., Buttler, G., Bereitschaft und Motivation der Studierenden der Wirtschafts- und Sozialwissenschaftlichen Fakultät der Universität Erlangen-Nürnberg zur Existenzgründung, Nürnberg, 1998.

31 Mueller S. L., Gender Gaps in "Potential for Entrepreneurship Across Countries and Cultures", Journal of Developmental Entrepreneurship, Vol. 9, Iss. 3, pg. 199-220, 2004.

32 Peterman, N.E. - Kennedy, J., "Enterprise Education: Influencing Students' Perceptions of Entrepreneurship", Entrepreneurship: Theory \& Practice, Vol. 28, Iss. 2, p.129-144, 2003.

33 Proctor, T., Essentials of Marketing Research, $2^{\text {nd }}$ Edition, Essex, 2000.

34 Reynolds, P.D. - Bygrave, W.D. - Autio, E. - Cox, L.W. - Hay, M., Global Entrepreneurship Monitor, Available at:

http://www.gemconsortium.org/category_list.aspx, 2002.

35 Rosa, P. - Carter, S. - Hamilton, D., "Gender as a Determinant of Small Business Performance": Insights from a British Study, Small Business Economics, Vol. 8, Iss. 6, p. 463-78, 1996.

36 Sandberg W. K., "An exploratory study of women in micro enterprises: gender-related differences", Journal of Small Business and Enterprise Development, Vol. 10, Iss. 4; pg. 408-417, 2003.

37 Schnell, R. - Hill, P. - Esser, E., Methoden der empirischen Sozialforschung, $5^{\text {th }}$ Edition, Munich, 1995.

38 Scott M.G. - Twomey D.F., "The long-term supply of entrepreneurs: Students' career aspirations in relation to entrepreneurship", Journal of Small Business Management, p. 5-13, 1988. 
39 Sexton, D. L.; Bowman-Upton, N., "Female and Male Entrepreneurs: Psychological Characteristics and Their Role in Gender-Related Discrimination". Journal of Business Venturing, Vol. 5, Iss. 1, p 29-36, 1990.

40 Singh, G. - DeNoble, A., "Views on Self-employment and Personality: An Exploratory Study", Journal of Developmental Entrepreneurship, Vol. 8, Iss. 3, p. 265-281, 2003.

41 Sternberg, R. - Bergmann, H. - Lückgen, I., Global Entrepreneurship Monitor: Länderbericht Deutschland 2003, Universität Köln, 2004.

42 Sternberg, R. - Bergmann, H. - Lückgen, I., Global Entrepreneurship Monitor: Länderbericht Deutschland 2004, Universität Köln, 2005.

43 Souitaris, V. - Zerbinati, S. - Al-Laham, A., "Do entrepreneurship programmes raise entrepreneurial intention of science and engineering students? The effect of learning, inspiration and resources", Journal of Business Venturing, Vol. 22, Iss. 4, p. 566-591, 2007.

44 Ufuk, H. - Özgen, Ö., "The profile of women entrepreneurs: a sample from Turkey", Journal of Consumer Studies and Home Economics, Vol. 25, Iss. 4, p. 299-308, 2001.

45 Verheul, I. - Thurik, R., "Start-Up Capital: 'Does Gender Matter?", Small Business Economics, Vol. 16, Iss. 4, p. 329-346, 2001.

46 Verheul, I., Commitment or control? Human resource management in female- and male-led businesses, Strategic Study B200206, available at http://www.eim.net/pdf-ez/B200206.pdf, 2003.

47 Verheul, I. - Van Stel, A. - Thurik, R., "Explaining female and male entrepreneurship at the country level", Entrepreneurship \& Regional Development, Vol. 18, Iss. 2, p.151 - 183, 2006.

48 Voigt, K.-I. - Brem, A. - Scheiner, Ch., Entrepreneurship Education and the "Study Cooperation"- Approach - Results from a Quantitative Empirical Analysis; Internationalizing Entrepreneurship Education and Training - Innovative Formats for Entrepreneurship Education Teaching - Proceedings, Nuremberg, 2006.

49 Wang C.K. - Wong P., "Entrepreneurial interest of university students" in Singapore. Technovation, No. 24, p. 163-172, 2004.

50 Wilson, F. - Marlino, D. - Kickul, J., "Our Entrepreneurial Future: Examining the Diverse Attitudes and Motivations of Teens Across Gender and Ethnic Identity", Journal of Developmental Entrepreneurship, Vol. 9, Iss. 3, p. 177-197, 2004.

51 Zikmund, W., Exploring Marketing Research, Chicago, 1982.

114 Volum 8, Număr 4, Decembrie 2007

Revista de Management Comparat Internațional 
Appendices

Hindering factors- intention-male sample

\begin{tabular}{|c|l|l|l|c|}
\hline & & & Model Summary \\
\hline Model & $\mathrm{R}$ & R Square & $\begin{array}{l}\text { Adjusted } \\
\text { R Square }\end{array}$ & $\begin{array}{l}\text { Std. Error of } \\
\text { the Estimate }\end{array}$ \\
\hline 1 &, $230(\mathrm{a})$ &, 053 &, 036 & 1,05316 \\
\hline
\end{tabular}

a Predictors: (Constant), social hindrances, lack of pre-start up know-how, lack of interest and ideas, financial and failure risk

ANOVA(b)

\begin{tabular}{|l|l|l|l|l|l|l|}
\hline Model & & $\begin{array}{l}\text { Sum of } \\
\text { Squares }\end{array}$ & df & $\begin{array}{l}\text { Mean } \\
\text { Square }\end{array}$ & F & Significance \\
\hline 1 & Regression & 13,723 & 4 & 3,431 & 3,093 &, $017(\mathrm{a})$ \\
& Residual & 246,233 & 222 & 1,109 & & \\
& Total & 259,956 & 226 & & & \\
\hline
\end{tabular}

a Predictors: (Constant), social hindrances, lack of pre-start up know-how, lack of interest and ideas, financial and failure risk

b Dependent Variable: intention

\begin{tabular}{|c|c|c|c|c|c|c|}
\hline \multicolumn{7}{|c|}{ Coefficients(a) } \\
\hline \multirow[t]{2}{*}{ Model } & & \multicolumn{2}{|c|}{$\begin{array}{l}\text { Unstandardized } \\
\text { Coefficients }\end{array}$} & \multirow{2}{*}{$\begin{array}{l}\text { Standardized } \\
\text { Coefficients } \\
\\
\text { Beta }\end{array}$} & \multirow[t]{2}{*}{$\mathrm{T}$} & \multirow[t]{2}{*}{ Significance } \\
\hline & & B & $\begin{array}{l}\text { Std. } \\
\text { Error }\end{array}$ & & & \\
\hline \multirow[t]{5}{*}{1} & (Constant) & 2,173 & ,322 & & 6,747 &, 000 \\
\hline & $\begin{array}{l}\text { lack of pre-start } \\
\text { up know-how }\end{array}$ &,- 081 &, 106 &,- 062 &,- 759 & ,448 \\
\hline & $\begin{array}{l}\text { financial } \\
\text { failure risk }\end{array}$ and &,- 093 &, 100 &,- 076 &,- 926 &, 356 \\
\hline & $\begin{array}{l}\text { lack of interest } \\
\text { and ideas }\end{array}$ &,- 168 &, 080 &,- 162 & $-2,099$ &, 037 \\
\hline & $\begin{array}{l}\text { social } \\
\text { hindrances }\end{array}$ &, 080 &, 078 &, 073 & 1,032 &, 303 \\
\hline
\end{tabular}

a Dependent Variable: intention 


\section{Hindering factors- intention- female sample}

\begin{tabular}{|c|c|c|c|c|}
\hline Model & $\mathrm{R}$ & R Square & $\begin{array}{l}\text { Adjusted } \\
\text { R Square }\end{array}$ & $\begin{array}{l}\text { Std. Error of } \\
\text { the Estimate }\end{array}$ \\
\hline 1 & ,277(a) & ,077 & ,062 & ,90792 \\
\hline
\end{tabular}

a Predictors: (Constant), social hindrances, lack of pre-start up know-how, lack of interest and ideas, financial and failure risk

ANOVA(b)

\begin{tabular}{|l|l|l|l|l|l|l|}
\hline Model & & $\begin{array}{l}\text { Sum of } \\
\text { Squares }\end{array}$ & df & $\begin{array}{l}\text { Mean } \\
\text { Square }\end{array}$ & F & Significance \\
\hline 1 & Regression & 16,817 & 4 & 4,204 & 5,100 &, $001(\mathrm{a})$ \\
& Residual & 202,784 & 246 &, 824 & & \\
& Total & 219,602 & 250 & & & \\
\hline
\end{tabular}

a Predictors: (Constant), social hindrances, lack of pre-start up know-how, lack of interest and ideas, financial and failure risk

b Dependent Variable: intention

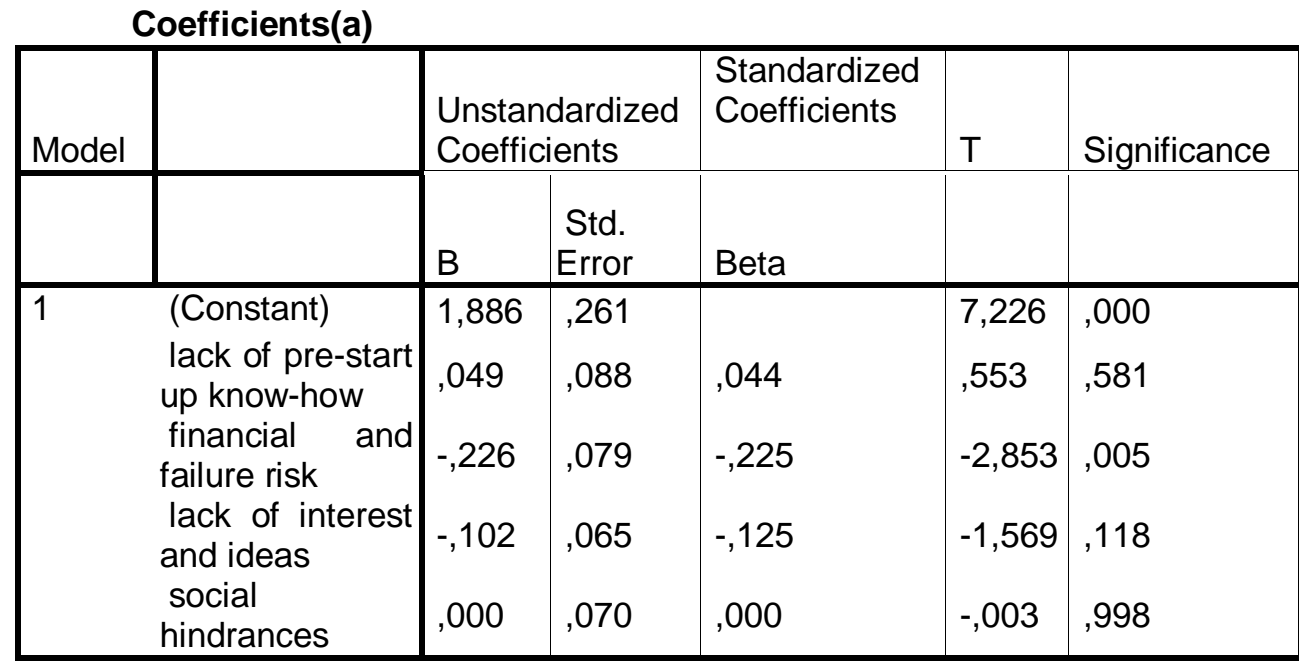

a Dependent Variable: intention 


\section{Fostering factors- intention- male sample}

\begin{tabular}{|c|c|c|c|c|}
\hline \multicolumn{5}{|c|}{ nary } \\
\hline Model & $\mathrm{R}$ & R Square & $\begin{array}{l}\text { Adjusted } \\
\text { R Square }\end{array}$ & $\begin{array}{l}\text { Std. Error of } \\
\text { the Estimate }\end{array}$ \\
\hline 1 & $301(a)$ & .090 & .074 & 1,02871 \\
\hline
\end{tabular}

a Predictors: (Constant), independence, status, external factors and experience

ANOVA(b)

\begin{tabular}{|l|l|l|l|l|l|l|}
\hline Model & & $\begin{array}{l}\text { Sum of } \\
\text { Squares }\end{array}$ & df & $\begin{array}{l}\text { Mean } \\
\text { Square }\end{array}$ & F & Significance \\
\hline 1 & Regression & 23,640 & 4 & 5,910 & 5,585 &, $000(\mathrm{a})$ \\
& Residual & 238,103 & 225 & 1,058 & & \\
& Total & 261,743 & 229 & & & \\
\hline
\end{tabular}

a Predictors: (Constant), independence, status, external factors and experience

b Dependent Variable: intention

Coefficients (a)

\begin{tabular}{|c|c|c|c|c|c|c|}
\hline Model & & \multicolumn{2}{|c|}{$\begin{array}{l}\text { Unstandardized } \\
\text { Coefficients }\end{array}$} & $\begin{array}{l}\text { Standardized } \\
\text { Coefficients }\end{array}$ & \multirow[t]{2}{*}{$\mathrm{T}$} & \multirow[t]{2}{*}{ Significance } \\
\hline & & & Std. Error & Beta & & \\
\hline \multirow[t]{5}{*}{1} & (Constant) &,- 419 &, 387 & & $-1,082$ &, 280 \\
\hline & Independence & ,323 &, 095 & ,245 & 3,382 & ,001 \\
\hline & Status &, 032 &, 079 & ,028 &, 399 &, 690 \\
\hline & External factors &,- 006 &, 078 &,- 005 &,- 075 &, 940 \\
\hline & Experience & 088 &, 083 & 081 & 1,051 & ,294 \\
\hline
\end{tabular}

a Dependent Variable: intention 


\section{Fostering factors- intention- female sample}

\begin{tabular}{|c|c|c|c|c|}
\hline & lel & iry & & \\
\hline Model & $\mathrm{R}$ & R Square & $\begin{array}{l}\text { Adjusted } \\
\text { R Square }\end{array}$ & $\begin{array}{l}\text { Std. Error of } \\
\text { the Estimate }\end{array}$ \\
\hline 1 & ,249(a) & ,062 & ,047 & ,91136 \\
\hline
\end{tabular}

a Predictors: (Constant), independence, status, external factors and experience

ANOVA(b)

\begin{tabular}{|c|c|c|c|c|c|c|}
\hline Model & & $\begin{array}{l}\text { Sum of } \\
\text { Square } \\
\mathrm{s}\end{array}$ & df & $\begin{array}{l}\text { Mean } \\
\text { Square }\end{array}$ & $\mathrm{F}$ & Significance \\
\hline 1 & $\begin{array}{l}\text { Regression } \\
\text { Residual } \\
\text { Total }\end{array}$ & $\begin{array}{l}13,525 \\
205,154 \\
218,679\end{array}$ & $\begin{array}{l}4 \\
247 \\
251\end{array}$ & $\begin{array}{l}3,381 \\
, 831\end{array}$ & 4,071 & ,003(a) \\
\hline
\end{tabular}

a Predictors: (Constant), independence, status, external factors and experience

b Dependent Variable: intention

Coefficients (a)

\begin{tabular}{|c|c|c|c|c|c|c|}
\hline \multirow[t]{2}{*}{ Model } & & \multicolumn{2}{|c|}{$\begin{array}{l}\text { Unstandardized } \\
\text { Coefficients }\end{array}$} & \multirow{2}{*}{$\begin{array}{l}\text { Standardized } \\
\text { Coefficients } \\
\text { Beta }\end{array}$} & \multirow[t]{2}{*}{$\mathrm{T}$} & \multirow[t]{2}{*}{ Significance } \\
\hline & & B & $\begin{array}{l}\text { Std. } \\
\text { Error }\end{array}$ & & & \\
\hline 1 & $\begin{array}{l}\text { (Constant) } \\
\text { Independence } \\
\text { Status } \\
\text { External } \\
\text { factors } \\
\text { Experience }\end{array}$ & $\begin{array}{l}-, 400 \\
, 214 \\
-, 025 \\
, 040 \\
, 128\end{array}$ & $\begin{array}{l}, 365 \\
, 091 \\
, 074 \\
, 066 \\
, 081\end{array}$ & $\begin{array}{l}, 163 \\
-, 024 \\
, 044 \\
, 118\end{array}$ & $\begin{array}{l}1,096 \\
2,341 \\
-, 337 \\
, 611 \\
1,568\end{array}$ & $\begin{array}{l}, 274 \\
, 020 \\
, 737 \\
, 542 \\
, 118\end{array}$ \\
\hline
\end{tabular}

b Dependent Variable: intention 